\title{
ТРУДОВА МІГРАЦІЯ В УКРАЇНІ У КОНТЕКСТІ ЗРОСТАННЯ СОЦІАЛЬНОЇ ТРАНЗИТИВНОСТІ СУЧАСНОГО СВІТУ
}

У статті розглянуто особливості трудових міграційних процесів в Украйні в ситуації зростання глобальної соияіальної і геополітичної транзитивності сучасного світу. Значна увага у дослідженні зосереджена на аналізі впливу результатів Industry 4.0. на зростання трудової міграції $і$ зміну ї̈ якісних характеристик. Автором встановлено, щуо трудова міграџія має переважно негативні наслідки для України (втрату найбільш активної молодої частини населення, руйнацію сімейних зв'язків у родинах трудових мігрантів, нелегальну або напівлегальну зайнятість украйнських трудових мігрантів, їх роботу

у важких, часто шкідливих умовах праці, пришвидшення процесу старіння нації, зростання ијін на товари і послуги в Украӥні за умови низької купівельної спроможності основної маси населення, недоступність для украӥнських трудових мігрантів кваліфікованої медичної допомоги у краӥні прибуття, втрату національної ідентичності мігрантів-україниів $і$ загрозу їх асиміляиііі).

Ключові слова: міграційні процеси, трудова міграція, міграџійна політика, соціальна транзитивність, глобалізачія, суспільство.

В умовах транзитивності сучасного глобалізованого світу посилення міграційних процесів стало однією 3 визначальних характеристик його нестабільності і мінливості. В ситуації посилення диспропорцій у розвитку різних країн світу, зростання міжнародних, міжетнічних, міжрелігійних конфліктів, локальних воєн, наростання рівня тероризму й екстремізму, зростання загрози природних і екологічних катаклізмів проблема міграції набула характеру комплексності й універсальності. Більше того міграційна проблема охопила практично усі сфери буттєвості людини, адже вона здійснюється в сучасному соціумі на основі економічних, політичних, релігійних, правових, освітніх та інших чинників. Найпоширенішими причинами міграції до цього часу залишається прагнення іiї суб'єктів подолати безробіття, підвищити свій життєвий рівень, уникнути військових конфліктів, возз'єднатися з родиною, отримати високий рівень освітніх послуг та ін. Як одна з важливих форм соціальних комунікацій міграція в сучасній соціально-філософській парадигмі небезпідставно вважається одним 3 факторів "м’якої" безпеки у глобалізованому світі, який часто дозволяє уникнути гуманітарних катастроф.

Внаслідок зростання соціальної і геополітичної транзитивності в сучасному світі відбувається збільшення обсягів трудової міграції та зміна ії якісних характеристик. Якщо у минулі століття трудова міграція була пов'язана переважно 3 економічною відсталістю, бідністю населення деяких регіонів планети та з наслідками світових військових конфліктів, то на початку XXI століття зростання трудової міграції співвідноситься і з переселенням у розвинуті країни світу науковців, представників сфери ITіндустрії, менеджерів високого класу та ін. Ці тенденції, з одного боку, мають об'єктивний характер, оскільки пов'язані з процесом якісного перерозподілу трудових ресурсів. Однак, з другого боку, вони засвідчують подальшу деградацію економічно відсталих регіонів світу і ще більше зростання нерівномірності у розвитку різних регіонів планети.

У науковій літературі проблема визначення атрибутивних ознак, причин та форм трудової міграції $\epsilon$ однією 3 найбільш затребуваних соціально-філософських тем. Означена проблематика знайшла відображення у працях М. Вербового, О. Вишневської, А. Гайдуцького, В. Гейця, О. Гладун, В. Свтуха, К. Кравчука, Ю. Макогона, О. Малиновської, О. Піскун, М. Романюка, А. Філіпенка, О. Хомри, М. Шульги та ін. Натомість специфіка зовнішньої трудової міграції стала предметом зацікавленості Р. Адамса, Ф. Дювела, О. Малиновської, Д. Массея, Е. Лібанової, І. Прибиткової, О. Пінчука, О. Позняка, О. Старка, Е. Тейлора, Т. Шульца та ін. Значна роль у вказаних дослідженнях присвячена і аналізу впливу глобалізації економічних процесів на сучасні форми виробництва та прискорення витіснення робочої сили $з$ традиційних, аграрних сфер виробничої діяльності. Утім, незважаючи на значний доробок вищевказаних дослідників, стрімка мінливість і транзитивність міграційної ситуації сучасності вимагає більш прискіпливого дослідження міграції в ситуації наростання глобалізаційних викликів перед країнами, які перебувають на периферії світової світ-системи та $\epsilon$ серйозним джерелом трудових ресурсів для розвинутих країн.

Метою статті є дослідження ключових тенденцій і наслідків трудової міграції в Україні в ситуації зростання соціальної транзитивності в епоху постіндустріалізму.

Однією $з$ ключових ознак постіндустріального суспільства, яке перебуває на порозі четвертої технологічної революції, стала зміна якості і напрямків міграційних процесів. На думку української 
дослідниці Н. Ковтун, це пов'язане з тим, що в умовах постіндустріалізму на фоні активної експлуатації просвітницьких ідей особистісного вдосконалення навіть найбільш соціально активні й освічені верстви населення не просто не можуть самореалізуватись, а й втрачають будь-яку надію на постійну роботу. У соціально-економічному житті постіндустріального суспільства зайвою виявилася не лише індустрія застарілих фабрик, заводів і цілих міст (Детройт, Клермонт, Ордос, Сан Жі, Фамагуста, Хуейчжоу), а й цілі соціальні верстви представників прекаріату [1:33]. В результаті четвертої технологічної революції роботу можуть втратити не лише звільнені через комп'ютеризацію і роботизацію працівники заводів і фабрик, а й значна частина представників обслуговуючої галузі та сфер медицини, освіти і культури. Ці тенденції у перспективі тільки посилюватимуть нестабільність ринку праці в Україні.

Зростання інтенсивності трудової міграції з України відбувається на фоні подальшої структурної деградації економіки нашої держави, зростання її сировинної складової, військових дій на Сході держави та анексії Криму. Ці процеси закономірно спровокували падіння рівня життя та масове зростання безробіття і стимулювали трудову міграцію за кордон, яка перетворилася на масове явище і джерело доходів багатьох сімей. "Відповідно до даних дослідження, проведеного в рамках проекту МОМ у 20142015 роках, за кордоном перебувають для здійснення трудової діяльності близько 700 тис. громадян України". За даними цього ж дослідження, серед трудових мігрантів переважають чоловіки, найбільш чисельнішими серед них є особи 30-40 років (понад $40 \%$ ). 41 \% трудових мігрантів мають середню або середню спеціальну освіту, 36 \% - вищу освіту [2]. Іншими словами, тисячі кваліфікованих фахівців, на підготовку яких витрачені значні державні кошти, не можуть реалізуватись у власній країні і змушені займатись важкою низько кваліфікованою роботою за кордоном.

У найближчі роки трудова міграція з України буде зазнавати і суттєвих якісних змін, пов'язаних, насамперед, з впливом четвертної індустріальної революції (Industry 4.), початок якої був проголошений у 2016 р. у м. Давосі. Одним з передвісників такого впливу стало переведення у кн. XX - на поч. XXI ст. цілих галузей виробництва $з$ території розвинутих країн Америки та Європи у країни, що розвиваються. Основним фактором такого переведення стала надзвичайно низька ціна робочої сили та менш жорсткі соціальні й екологічні вимоги до виробництва у країнах третього світу. Результатом цього стало зростання безробіття на території розвинутих країн Європи та Америки і як наслідок збільшення рівня внутрішньої трудової міграції. У зв'язку з цим згадані країни вводять на сучасному етапі ще жорсткіші міграційні правила для іноземних громадян.

Слід враховувати й те, що переведення виробництва у країни, які розвиваються, не стало виключно позитивним фактором для їх розвитку. Мізерна заробітна плата, відсутність належних соціальних стандартів, ненормований робочий день, використання дитячої праці, порушення екологічних стандартів у процесі виробництва нівелюють позитивний потенціал нових виробничих потужностей. Відтак, поява таких підприємств не може якісно вплинути на зростання рівня виробництва і подолання економічної відсталості країн-реципієнтів.

У результаті четвертої технологічної революції все більше з'являтимуться підприємства (фабрики, банки, офіси, магазини), де виробництво і надання послуг набуватимуть ознак тотальної автоматизації, роботизації й інтернетизації. Прямим наслідком цього буде звільнення сотень тисяч робітників і службовців, які поповнюватимуть клас "лишніх людей", насамперед, у розвинутих країнах світу. Отже, загроза зростання стихійної трудової міграції буде виходити не лише від країн, що розвиваються, а й від країн "золотого мільярду".

В Україні прийнято цілий ряд нормативних документів, які регулюють трудову міграцію. До них належить, насамперед, концепція державної міграційної політики, затверджена Указом Президента України від 30 травня 2011 р. Вона визначає напрями, стратегічні завдання державної міграційної політики України, принципи і пріоритети діяльності державних органів у сфері міграції, напрями вдосконалення іiі законодавчого та інституційного забезпечення, а також механізми реалізації означеної концепції [3]. Реалізація цієї концепції мала сприяти забезпеченню ефективного державного управління міграційними процесами, створенню умов для сталого демографічного та соціально-економічного розвитку держави, підвищенню рівня національної безпеки шляхом запобігання виникненню неконтрольованих міграційних процесів та ліквідації їх наслідків, узгодження національного законодавства у сфері міграції з міжнародними стандартами, посиленню соціального і правового захисту громадян України та ін.

Також було прийнято Державну програму співпраці з закордонними українцями на період до 2015 р., метою якої мало стати здійснення центральними та місцевими органами виконавчої влади заходів щодо забезпечення співпраці із закордонними українцями, збереження їх національно-культурної ідентичності, використання інтелектуального, культурного та духовного потенціалу закордонних українців 3 метою утвердження позитивного міжнародного іміджу України, а також забезпечення підтримки закордонних українських громад [4].

Значна роль у розв'язанні проблем трудових мігрантів відводиться Уповноваженому Верховної Ради України з прав людини. Серед громадських організацій слід згадати й діяльність Всеукраїнської 
громадської організації "Українська взаємодопомога", створеної у листопаді 2003 р. Метою цієї організації стало опікування проблемами українських громадян та їх родин за кордоном і в Україні. Саме ця організація зініціювала громадянський проект "Четверта хвиля", метою якого є консолідація громадян України, що проживають за кордоном, для реалізації їх громадянських, професійних, соціальних, економічних прав, підтримки фахових інтересів і профспілкової солідарності та сприяння їх поверненню в Україну [5: 100]. Одним із завдань діяльності "Четвертої хвилі" є налагодження взаємодії "нової" і "старої" української еміграції. Внаслідок цього були сформовані новітні українські громадські організації у Греції, Канаді, Італії, Іспанії, Португалії, США та ін. Загалом українська держава має виробляти стратегічну позицію щодо унормування зовнішньої трудової міграції, перевівши іiї у цивілізовані правові форми.

Незважаючи на значну законодавчу базу регуляції трудової міграції в Україні, правовий статус українських мігрантів залишається доволі суперечливим. Так, за даними Міжнародної організації міграції на 2015 р. лише в 2012-2014 рр. під час виїзду за кордон на роботу або з метою шлюбу від торгівлі людьми постраждали понад 40 тис українців [6]. У поєднанні з результатами досліджень, що були здійснені на замовлення МОМ (2012 р.), за період з 1991 р. понад 160 тис. українців постраждали від торгівлі людьми [7: 29]. Статистичні дані також засвідчують, що в умовах економічної кризи і різкого падіння добробуту населення ризик потрапити в подібну ситуацію лише зростає. Так, за даними МОМ на 2015 р. 21 \% потенційних трудових мігрантів з України погодилися б заради роботи в іншій країні перетнути кордон нелегально, працювати під замком або віддати свій паспорт працедавцю. За даними аналогічного дослідження 2011 р. особи, схильні приймати сумнівні пропозиції працевлаштування за кордоном становили лише 14 \% від загальної кількості потенційних трудових мігрантів [7: 29-30]. Посилення експлуатації українських трудових мігрантів посилюється й тим, що емігрують переважно особи з середньою спеціальною або вищою освітою, кваліфіковані спеціалісти, які за кордоном зайняті переважно на некваліфікованих роботах. Лише незначній частині українських трудових мігрантів, насамперед зі сфери IT, вдається знайти за кордоном достатньо високооплачувану й престижну роботу.

3 метою нівеляції торгівлі людьми в Україні прийнято закон "Про протидію торгівлі людьми", який завбачує надання таким особам офіційного статусу особи, що постраждала від торгівлі людьми. Згідно 3 даними представництва МОМ в Україні з січня 2000 р. до червня 2016 р. комплексну реінтеграційну допомогу отримали в Україні 12186 постраждалих, зокрема юридичну, медичну, психологічну, фінансову, освітню та ін. Серед одержувачів допомоги переважають чоловіки. Більшість (52\%) постраждалих у 2014-2015 р. становлять молоді люди до 35-ти років; 73 \% постраждалих мають середню спеціальну або вищу освіту; 57 \% походять з обласних центрів (хоча до 2014 р. більшість 3 них була 3 сільської місцевості), що відображає загальне погіршення економічної ситуації в Україні [7: 30]. За статистичними даними 46 \% одержувачів допомоги у 2010-2015 рр. постраждали від торгівлі людьми в Росії, $13 \%$ - у Польщі, $13 \%$ - у інших країнах СC, $11 \%$ - у Туреччині. Постраждалі в межах України становили лише $6 \%$ [7: 31].

В Україні на сучасному етапі здійснюється ціла низка заходів щодо боротьби з торгівлею людьми. У 2018 р. за твердженням заступника міністра внутрішніх справ України Т. Ковальчук, завдяки новим підходам до кримінального аналізу та підготовки правоохоронців та співпраці 3 міжнародними інституціями, які протидіють торгівлі людьми, Україна вийшла зі списку країн, які не відповідають мінімальним стандартам протидії торгівлі людьми. Так, у 2017 р. силами працівників системи МВС була припинена діяльність 29 організованих злочинних груп, які займалися торгівлею людьми. При цьому кількість зареєстрованих справ у сфері торгівлі людьми зросла до 346, тоді як у 2016 році зареєстровано 115 випадків [8]. Однак, не зважаючи ці заходи, в Україні ще рано говорити про суттєві успіхи в цій галузі. Існують й об’єктивні чинники цієї ситуації. Вказаний вид злочинів, порівняно 3 торгівлею наркотиками і зброєю, посідає важливе місце у структурі кримінальної діяльності, адже навіть у випадку доведення вини в суді, вирок для злочинців у цій сфері складає не більше п'яти років загального режиму. Окрім того він часто замінюється на умовний строк або звільнення за амністією. Відтак, не дивно, що в Україні в останні роки з'явилася маса легальних і напівлегальних "агенцій 3 працевлаштування за кордоном". Слід зауважити, що нівеляція їх негативного впливу можлива і через механізми безвізового в’їзду громадян України в країни ЄС. У перспективі це має зменшити рівень нелегальної трудової міграції і торгівлі людьми.

В цілому, масова трудова міграція має неоднозначні і переважно негативні наслідки для України. До негативних наслідків трудової міграції з України слід віднести втрату найбільш мобільної молодої частини населення, окреме проживання членів родини та руйнацію сімейних зв'язків, нелегальну або напівлегальну зайнятість українських трудових мігрантів, роботу у важких, часто шкідливих умовах праці, низьку заробітна плата та малокваліфіковану роботу, незворотні втрати держави внаслідок нерентабельності капіталовкладень у сферу освіти через міграцію працівників в інші країни, пришвидшення процесу старіння нації та наростання дисбалансу на внутрішньому ринку праці, зростання цін на товари і послуги за умови низької купівельної спроможності основної маси населення, 
недоступність для мігрантів кваліфікованої медичної допомоги у країні прибуття, втрату національної ідентичності мігрантів-українців і загрозу їх асиміляції та ін. До негативних наслідків трудової міграції 3 України належить і те, що нелегальна трудова міграція не сприяє наповненню пенсійного і соціального фондів через відсутність відрахувань від заробітної плати трудових мігрантів. При цьому повернення трудових мігрантів пенсійного віку в Україну ще більше посилює тиск на систему державного соціального забезпечення. Поряд 3 цим масова трудова міграція посилює й загрозу ще швидшої депопуляції України. Так за даними офіційного перепису населення в Україні нараховується приблизно 48 млн. громадян, включно 3 тими, які перебувають на заробітках за кордоном. При цьому майже половина населення держави належить до категорії непрацездатних (неповнолітні, пенсіонери, інваліди). За багатьма параметрами Україна вже перебуває на межі демографічної катастрофи. Це пов'язане з тим, що трудовими мігрантами стають переважно активні фізично здорові, молоді, певним чином фінансово забезпечені громадяни. Для них зазвичай властива практичність, працьовитість, мобільність, заповзятливість, схильність для ризику та ін. Втрата таких громадян призводить до ще більшого поглиблення соціально-економічної кризи в Україні. У зв'язку з цим, саме вироблення механізмів збереження людського освіченого потенціалу стає найбільш нагальною проблемою вітчизняного політичного і суспільного дискурсу.

До умовно позитивних наслідків масової трудової міграції з України належить зниження тиску на ринок праці та зменшення соціальної напруги в українському суспільстві, зменшення навантаження на сферу соціальної допомоги, можливість підвищення добробуту окремих категорій працівників, здобуття ними нового професійного досвіду, отримання нової мовної практики, набуття досвіду життя в демократичному правовому суспільстві та ін.

Нівеляція негативних наслідків масової трудової міграції є нагальним завданням для України. Незважаючи на деякі кроки, зроблені українським урядом у 2017 р., підвищення мінімальної заробітної плати до 3200 грн., в Україні досі відсутня системна міграційна політика. Вона має виходити з ідеї, що нівеляція міграційних втрат можлива через комплексне реформування і лібералізацію ведення бізнесу, формування позитивного інвестиційного клімату, створення нових робочих місць 3 належною оплатою праці, розв'язання житлової проблеми та ін. Водночас міграційна політика має захистити державу від напливу нелегальної міграції з третіх країн та гарантувати легальним українським мігрантам інтеграцію у розвинуті суспільства на правовій основі або сприяти їх поверненню до України. У ситуації наростаючої соціальної транзитивності саме держава має взяти на себе регламентацію умов в’ізду і перебування іммігрантів на своїй території на підставі національних інтересів і завдань транснаціональної безпеки.

Слід враховувати те, що активізація трудової міграції з України пов'язана як з внутрішніми, так і 3 зовнішньополітичними чинниками. 3 одного боку, Україна має специфічні причини трудової міграції, пов'язані з низькою заробітною платою та високим рівнем безробіття, анексією Криму та російською агресією на Сході України. 3 другого боку, поряд з системним наростанням несприятливих внутрішніх умов, що "виштовхують" мобільних економічно активних громадян за кордон Угода про асоціацію з СС (2014) відкрила якісно нові можливості для відпливу працівників 3 держави. Основними країнами призначення трудових мігрантів з України стали Польща, Російська Федерація, Чеська Республіка та Італія. Саме на них припадає близько 80 \% загальних потоків українських трудових мігрантів. Якісно новим чинником активізації трудової міграції з України є вплив на українську економіку суперечливих результатів Industry 4.0. і як наслідок загострення проблеми перерозподілу матеріальних багатств між бідними і багатими громадянами однієї країни та між економічно відсталими і розвинутими державами і регіонами світ-системи.

\section{СПИСОК ВИКОРИСТАНИХ ДЖЕРЕЛ ТА ЛІТЕРАТУРИ}

1. Ковтун Н. М. Криза світоглядно-ціннісних орієнтацій в ситуації транзитивності постіндустріального суспільства // Вісник Житомирського державного університету імені Івана Франка. - Житомир : Вид-во ЖДУ ім. І. Франка, 2017. - Випуск № 1 (87). - С. 32-36.

2. Міграція як чинник розвитку в Україні [Електронний ресурс]. - К. : МОМ, 2016. - Режим доступу: $\mathrm{http}: / /$ www.iom.org.ua/sites/default/files/mom_migraciya_yak_chynnyk_rozvytku_v_ukrayini.pdf.

3. Концепція державної міграційної політики : Указ Президента України № 622/2011 від 30.05.2011р. [Електронний pecypc]. - Режим доступу : http:// zakon2.rada.gov.ua/laws/show/622/2011.

4. Про схвалення Концепції Державної програми співпраці із закордонними українцями на період до 2015 року : Розпорядження Кабінету Міністрів України № 572-р від 22.06.2011р. [Електронний ресурс]. - Режим доступу : http://iom.org.ua/ua/ legislation-ukr/migration-related-legislation-ukr/state-program-of-cooperationwithukrainians-living-abroad.html.

5. Васильківський Д. М. Зовнішня трудова міграція в Україні: сучасний стан, причини, наслідки / Д. М. Васильківський, О. А. Осійчук // Вісник Хмельницького національного університету. - 2009. - № 1. C. $97-101$.

6. Дослідження з питань міграції та торгівлі людьми : Україна, 2015 [Електронний ресурс]. - Режим доступу : http://iom.org.ua/sites/default/files/pres_kit_gfk_iom2015_ua_fin_3_2.pdf. 
7. Міграція в Україні : факти і цифри / Упорядник Олена Малиновська. - К. : МОМ, 2016. - 32 с.

8. Ковальчук Т. За рік Україні вдалося вийти з групи країн, де процвітає торгівля людьми [Електронний ресурс]/ Тетяна Ковальчук. - Режим доступу: http://mvs.gov.ua/ua/news/12352_Tetyana_Kovalchuk_Za_rik_Ukraini_vdalosya_viyti_z_grupi_krain_de_procvita _torgivlya_lyudmi_htm (28.02.2018).

\section{REFERENCES (TRASLATED \& TRANSLITERATED)}

1. Kovtun N. M. Kryza svitohliadno-tsinnisnykh oriientatsii v sytuatsii tranzytyvnosti postindustrial'noho suspilstva [The Crisis of Outlook and Value Orientations in Transitiveness Situation in Post-industrial Society] // Visnyk Zhytomyrskoho derzhavnoho universytetu imeni Ivana Franka [Zhytomyr Ivan Franko State University Journal]. Zhytomyr : Vyd-vo ZhDU im. I. Franka, 2017. - Vypusk № 1 (87). - S. 32-36.

2. Mihratsiia yak chynnyk rozvytku v Ukraini [Migration as Factor of Development is inUkraine] [Elektronnyi resurs]. - K. : MOM, 2016. - Rezhym dostupu : http://www.iom.org.ua/sites/default/files/mom_migraciya_yak_chynnyk _rozvytku_v_ukrayini.pdf.

3. Kontseptsiia derzhavnoi mihratsiinoi polityky : Ukaz Prezydenta Ukrainy № 622/2011 vid 30.05.2011 r. [Conception of Public Migratory Policy : Decree of President of Ukraine № 622/2011 from 30.05.2011] [Elektronnyi resurs]. - Rezhym dostupu : http:// zakon2.rada.gov.ua/laws/show/622/2011.

4. Pro skhvalennia Kontseptsii Derzhavnoi prohramy spivpratsi iz zakordonnymy ukraintsiamy na period do 2015 roku [About Approval of Conception of the Government Program of Collaboration with Foreign Ukrainians on a Period of 2015] : Rozporiadzhennia Kabinetu Ministriv Ukrainy № 572-r vid 22.06.2011 r. [Elektronnyi resurs]. Rezhym dostupu : http://iom.org.ua/ua/ legislation-ukr/migration-related-legislation-ukr/state-program-of-cooperationwithukrainians-living-abroad.html.

5. Vasylkivskyi D. M. Zovnishnia trudova mihratsiia v Ukraini : suchasnyi stan, prychyny, naslidky [External Labour Migration in Ukraine : the Modern State, Reasons, Consequences] / D. M. Vasylkivskyi, O. A. Osiichuk // Visnyk Khmelnytskoho natsional'noho universytetu [Herald of Khmelnytskyi National University]. - 2009. - № 1. - S. 97101.

6. Doslidzhennia z pytan' mihratsii ta torhivli liudmy : Ukraina, 2015 [Research on People's Questions Concerning Migration and Trading : Ukraine, 2015] [Elektronnyi resurs]. - Rezhym dostupu : http://iom.org.ua/sites/default/files/pres_kit_gfk_iom2015_ua_fin_3_2.pdf.

7. Mihratsiia v Ukraini : fakty i tsyfry [Migration in Ukraine : Facts and Numbers] / Uporiadnyk Olena Malynovska. K. : MOM, 2016. -32 s.

8. Kovalchuk T. Za rik Ukraini vdalosia vyity z hrupy krain, de protsvitaie torhivlia liudmy [In the Year Ukraine Succeeded to Exit from a Group of Countries Where Trafficking in Human Beings Is Flourishing]/ [Elektronnyi resurs] / T. Kovalchuk. $\quad-\quad$ Rezhym dostupu : http://mvs.gov.ua/ua/news/12352_Tetyana_Kovalchuk_Za_rik_Ukraini_vdalosya_viyti_z_grupi_krain_de_procvita _torgivlya_lyudmi_htm (28.02.2018).

\section{Коваленко О. В. Трудовая миграция в Украине в контексте роста социальной транзитивности современного мира.}

В статье рассмотрено особенности трудовых миграцчионых процессов в Украине в ситуации роста глобальной соччильной и геополитической транзитивности современного мира. Особое внимание в исследовании сконцентрировано на анализе влияния результатов Industry 4.0. на увеличение трудовой миграции и изменение ее качественных характеристик. Автором доказано, что трудовая миграция имеет преимущественно негативные последствия для Украины (утрату наиболее активной молодой части населения, уничтожение родственных связей в семьях трудовых мигрантов, нелегальную и полулегальную занятость украинских трудовых мигрантов, их работу в трудных, часто вредных условиях работы, ускорение процесса старения нации, рост иен на товары и услуги в Украине на фоне низкой покупательной способности основной массы населения, недоступность для украинских трудовых мигрантов квалифицчированной медицинской помощчи в стране прибытия, утрату национальной идентичности мигрантов-украинцев и угроза их ассимиляции).

Ключевые слова: миграционные процессы, трудовая миграция, миграционная политика, социиальная транзитивность, глобализация, общество.

\section{Kovalenko O. V. Labor Migration in Ukraine in the Context of Social Transitivity of the Modern World Increasing.}

In the article peculiarities of migration processes in Ukraine in the conditions of modern world global social and geopolitical transitivity are observed. In the research work much attention is paid to analysis of results of Industry 4.0. influence on the growth of labor migration change of its qualitative characteristics. It was stated by the author that labor migration has mostly negative consequences for Ukraine (the loss of the most active youth, destruction of family ties in the families of labor migrants, illegal or semi-legal employment of Ukrainian labor 
migrants, their work in heavy, often harmful working conditions, accelerating the aging process of the nation, increase in prices for goods and services in Ukraine provided the low purchasing power of the general population, inaccessibility for Ukrainian labor migrants to receive qualified medical care in the country of arrival, loss of national identity of Ukrainian migrants and the threat of their assimilation). Instead, the conditionally positive consequences of mass labor migration from Ukraine are as follows: reducing pressure on the labor market and reducing social tension in Ukrainian society, reduce the burden on the social assistance sector, the possibility of increasing the welfare of certain categories of workers, their gaining new professional experience, getting new linguistic practice, gaining an experience of life in a democratic legal society.

Key words: migration processes, labor migration, migration policy, social transitivity, globalization, society. 